\title{
Effect of teacher's performance in the implementation of environmental education to the student's active participation in maintaining environmental sustainability
}

\author{
Kristalinawati $^{1}$, S. W. Utomo ${ }^{2,3^{*}}$, T. E. B. Susilo ${ }^{3}$ \\ ${ }^{1}$ Senior High School of Gonzaga, Jakarta, Indonesia \\ 2Department of Environmental Health, Faculty of Public Health, University of Indonesia, Depok, Indonesia \\ ${ }^{3}$ Environmental Science Study Program, School of Environmental Sciences, University of Indonesia, \\ Jakarta, Indonesia
}

\begin{abstract}
Abstrak
Pendidikan lingkungan telah dimulai di Indonesia sejak tahun 1970, namun kerusakan lingkungan yang berasal dari perilaku manusia masih terjadi dan bahkan meningkat. Ini mungkin menyiratkan bahwa hasil pendidikan lingkungan belum terlihat. Kinerja guru sebagai pendidik dan perancang pembelajaran perlu dievaluasi. Penelitian ini dilakukan di SMA Gonzaga, Jakarta dan SMA Loyola, Semarang dengan pendekatan kuantitatif dan data kualitatif sebagai pendukung. Metode yang digunakan adalah survei dengan teknik kuesioner dan wawancara mendalam. Hasil penelitian menunjukkan bahwa partisipasi aktif siswa dalam hal melindungi lingkungan sangat rendah, yang berarti bahwa efektivitas pendidikan lingkungan tidaklah efektif. Kinerja guru sebagai pendidik dan perancang pembelajaran dalam penerapan pendidikan lingkungan memengaruhi partisipasi aktif siswa dalam pelestarian lingkungan. Pelatihan bagi guru dalam membuat instrumen pembelajaran mengenai pelaksanaan pendidikan lingkungan yang lebih efektif perlu dilakukan.
\end{abstract}

Kata kunci: pendidikan lingkungan, kinerja guru, partisipasi aktif siswa, skenario pengajaran

\begin{abstract}
.
Environmental education (EE) has begun in Indonesia since 1970 , however the environmental damages that come from human behaviour are still going on and even increasing. This may imply that the results of environmental education have not been seen. Performance of teachers as educators and learning designers need to be evaluated. The research was conducted at Gonzaga High School in Jakarta and Loyola High School in Semarang with a quantitative approach and qualitative data as supporters. The method used was survey, with questionnaires technique and in-depth interviews. The results show that the active participation of the students in terms of protecting the environment is very low. It means the effectiveness of environmental education in terms of this side is not effective. Performance of teachers as educators and learning designers in the implementation of EE affects the active participation of students in terms of conserving the environment. Training for teachers in making learning instrument needs to be done regarding the conduct of learning related EE more effective.
\end{abstract}

Keywords: environmental education, teacher's performance, student's active participation, teaching scenario

\section{INTRODUCTION}

The environmental damage occurring in various places in Indonesia largely derived from destructive human behaviour. A number of cases of pollution and damage in the sea, forests, atmosphere, water, soil and so on stem from irresponsible, indifferent and self-centred human behaviour (Keraf 2010). Taking all the necessities of nature regardless of its sustainability is regarded as justification, since nature is seen only for the benefit of humanity. Individuals as part of the group take part in making decisions that can harm the environment. Decisions made in the use of natural resources would be wise if provided with

\footnotetext{
${ }^{*}$ Korespondensi Penulis

Email : suyudwarno@gmail.com
} 
knowledge of the environment and deep understanding of the losses to be borne by living beings and future generations (Widiasih 1999).

Education plays an important role in environmental management. Human as the main actor in development plays an important role. The development can still run with optimal results within the environmental carrying capacity, so that the environment aspect is considered in order to maintain the preservation of its function. A paradigm shift in society in managing the environment and natural resources must exist, to engage the community actively in preserving the function of the environment. Development and environment are two interrelated matters, development is the power to improve the quality of life by utilizing all its supporting resources through the change of the environment in order to improve the overall standard of living (Soerjani 2002). Various efforts to realize sustainable development in the form of vision, regulation and action plan, all will lead to the attitude and behaviour of humans as the actors and objects in development. Human dimension in realizing sustainable development becomes a very decisive factor (Sugandhy and Hakim 2007).

Formal education in schools helps prepare human resources who are aware of the importance of preserving environmental functions and participating in environmental management in every action. According to Soemantojo (2004) educational institution in charge of preparing the reliable human resources in the field, aware of the limitations to the carrying capacity of the environment and natural resources, can act wisely to take advantage of the environment, aware of its role as a khalifah on this earth. Formal environmental education (EE) needs to be given early on. The purpose of EE in senior high schools should be more toward the cultivation of consciousness, providing basic knowledge, nurturing attitudes and increasing participation. In order for the direction and implementation of EE to be carried out properly, it is necessary to make guidelines contained in the curriculum called the greening curriculum.

Based on Law Number 32 of 2009 on Environmental Management and Protection Number, article 65 (2): "Everyone is entitled to environmental education, access to information, access to participation and access to justice in fulfilling the right to a good and healthy environment". This means the position of environmental education in the curriculum of education should be done to open up insight about the importance of environment. The objectives of environmental education formulated in Belgrade Charter 1975 in Belgrade, Yugoslavia, are summarized as follows: a) Increasing awareness and attention to economic, social, political and ecological linkages, both in urban and rural areas; b) Give everyone the opportunity to acquire the knowledge, skills, attitudes/behaviours, motivations and commitments required to work individually and collectively to solve current environmental problems and 
prevent new problems from emerging; c) Creating a unity of new behaviour patterns on the environment for individuals, groups and society (UNESCO 1975). Efforts to develop environmental education in Indonesia have been done since the 70s, but environmental damage is still happening and even increasing. This can be interpreted that environmental education in Indonesia has not shown tangible results. The performance of teachers as the spearhead of the implementation of EE is still questionable. Based on this, it can be asked research questions as follows:

1. How is the student's active participation in maintaining environmental sustainability?

2. How is the performance of teachers in of Gonzaga High School, Jakarta and Loyola High School, Semarang in terms of running its role to develop environment-based learning methods, as well as the development of curricular activities that can improve students' knowledge and awareness about the environment?

3. How is the influence of performance of the teachers in the implementation of environmental education on the active participation of students in terms of maintaining environment sustainability?

\subsection{Active participation of students}

Student behaviour on environmental problems in this research is seen from its active participation in facing environmental problems. Participation is a very often used word in development. According to Mikkelsen (2003) the word participation means: a) voluntary contributions from the community to a project without taking part in decision making; b) sensitization of community stakeholders to improve acceptability and ability to respond to development projects; c) an active process, meaning that the relevant person or group takes the initiative and uses its freedom to do so; d) strengthening dialogue between local communities and staff preparing, implementing, monitoring projects in order to obtain information on local context and social impacts; e) voluntary involvement by the community in the changes determined by itself; and f) community involvement in self-development, life and their environment

Associated with the above description it can be interpreted that someone can be said to participate is if the person participates in an activity, participation and participate. According to Chusmeru (2001) participation is essentially the degree of optimal awareness based on the construction of the mind built by one knowledge so as to give one motivation until the occurrence of a physical activity.

Based on Finch's research (2008), environmental education does not change the behaviour of the community because since their children have lost the opportunity to have experience in direct contact with nature so as not to be 
embedded with respect for nature. Public opinion polls in America reflect this trend, especially when closed questions force people to choose priorities (by imitating real life). In the poll, only $1 \%$ to $3 \%$ of the respondents placed the environment as their primary concern, much lower than in the previous 25 years. Much research has been done to examine the impact of knowledge on personal behaviour. Most evidence suggests there is no clear causal relationship between knowledge and behaviour. The Research by team of the Research Center for Human Resources and Environment (PPSML), University of Indonesia (1993) which was conducted at Senior High School 8 (SMAN 8) and Senior High School 38 (SMAN 38) Jakarta also indicate that the level of students' knowledge of the environment is not related to their attitude on environmental issues.

Barab and Roth (2006) conveys the concept of an ecological view of learning and participation, one that focusing on helping students to complete the invariant buildings underlying their understanding. From an ecological perspective, learning is the process of being prepared to engage effectively in the dynamic networking of the world by aiming at a particular goal. Much research has shown how the environment perceptually determines the possibilities for action. Three components of the framework can be done in the more general conceptualization of ecological learning, the ecosystem approach can be done in three steps. First, knowledge involving the participation of complex networks; the arrangement of the underlying provisions (such as facts, concepts, principles) is the basis of a person's network of capabilities tied to multiple usage contexts; and to really know a more specific source requires appreciation in the context of this usage. Second, the purpose of the school is to provide a movement that encourages one's participation; rather than expecting students to develop their own understanding that they can gain in the context of diverse uses. Third, the desired task or situation is designed by the educator by involving a network partner who has a very different ability from the concepts that have been lived in the lives of the students.

\subsection{Teachers as educators and designers of learning}

There are different concepts of teachers as teachers and teachers as educators. Teachers as educators play more than teachers who deliver certain subjects, but rather as models for character formation. His presence, attitudes, thoughts, values, concerns, commitments and visions are important dimensions that indirectly teach the values that shape the character of the student. The first principle for the development of the existence of teachers as character educators is their ability to live the vision and inspiration that becomes the soul for their professional performance. The world is changing, society is changing and the order of values is changing, it becomes a challenge for teachers to live their vision 
and inspiration that become the soul for the performance of educational institutions (Koesoema 2009).

In line with the competence as the teacher, teachers are required to be able to plan teaching. Teachers can design the curriculum according to the condition of the school and its students. Wiggins and McTighe (2005) provides a somewhat reversed curriculum design model that is commonly applied in Indonesia. In his view, after establishing the expected outcome or objective objectives, the teacher then determines the evidence of evidence, the type of behaviour, or a particular product, proving that the result has been achieved by the student. After paying attention to this type of invoice, the teacher then determines the appropriate type of knowledge ansd skills in the teaching strategy (syllabus, lesson plan).

Teachers as learning designers should seek appropriate methods in their learning, so that learning objectives can be achieved. Media and learning devices should be prepared by the teacher with considerations. Rideout's study (2005) indicate that the use of a module containing readings on environmental issues and energy crises used to support discussion, research and presentation activities can encourage the increased knowledge and consistency of decisionmaking in behaving, which in turn behaves pro-environment.

\section{METHODOLOGY}

\subsection{Study location}

This research was conducted on 47 teachers of Gonzaga High School which is located at Jalan Pejaten Barat Number 10A, South Jakarta and 48 teachers of Loyola High School which is located at Jalan Karanganyar Number 37, Semarang and XII class students in both of schools which amounts to 437 students.

\subsection{Research methods}

This research was cross sectional so it cannot state causation. The approach used in this study was a quantitative approach that also uses qualitative data. The method used was a survey while the data collection techniques used questionnaires and in-depth interviews. The research variables in this study are clarified in Table 1.

Table 1. Research variables.

\begin{tabular}{llcc}
\hline Research objectives & Research variable & Type of data & Data analysis \\
\hline $\begin{array}{l}\text { To identify the active } \\
\text { participation level of students in } \\
\text { maintaining environment }\end{array}$ & Active participation & Ordinal & $\begin{array}{c}\text { Descriptive } \\
\text { analytics }\end{array}$ \\
$\begin{array}{l}\text { To evaluate the performance of } \\
\text { teachers in implementing the } \\
\text { environmental sustainability }\end{array}$ & Performance of teachers & Ordinal & $\begin{array}{c}\text { Descriptive } \\
\text { analytics }\end{array}$
\end{tabular}




\begin{tabular}{llcc}
\hline Research objectives & Research variable & Type of data & Data analysis \\
\hline $\begin{array}{l}\text { To analyse the effect of teacher's } \\
\text { performance on the student's } \\
\text { active participation }\end{array}$ & $\begin{array}{l}\text { Performance of teachers } \\
\text { and active participation } \\
\text { of students }\end{array}$ & Nominal & $\begin{array}{c}\text { Descriptive } \\
\text { analytics }\end{array}$ \\
\hline
\end{tabular}

\subsection{Data analysis procedure}

\subsubsection{Determining the student's active participation}

To determine the level of active participation of students, the following steps are taken:

a) Determining the interval scale

b) Determining the scale of all answers

c) Determining the position of a person's active participation level on a scale

The interval scale is determined in the following equation (Equation 1):

Interval Scale $=\frac{(h x i)-(l x i)}{a}$

Description:

$\mathrm{h}$ : The highest scale value (multiplier factor multiplier)

l : The lowest scale value

a : The number of alternative answers (as the denominator)

i : The number of items of student active participation statement/teacher's performance

The calculation of interval scale in determining the student's active participation is presented as follows:

Interval Scale $=\frac{(5 \times 20)-(1 \times 20)}{5}=16$

Active participation of student is measured by asking questions about the frequency of student involvement when facing environmental problems. Active participation of respondents in terms of preserving the environment is determined by summing the scores of the questionnaires. There are 20 questions asked with a choice of answers: never (score 1), rare (score 2), sometimes (score 3 ), often (score 4) and always (score 5). The scores achieved were then compared with the scales in Table 2. After obtaining the criteria per individual, then viewed the student's overall active participation on population by looking at the number of students included in the high and very high criteria (Table 3 ).

Table 2. Criteria for student's active participation.

\begin{tabular}{cl}
\hline Total score & Criteria \\
\hline $20-36$ & Participation in maintaining environmental sustainability is very low \\
$37-52$ & Participation in maintaining environmental sustainability is low \\
$53-68$ & Participation in maintaining environmental sustainability is moderate \\
$69-84$ & Participation in maintaining environmental sustainability is high \\
$85-100$ & Participation in maintaining environmental sustainability is very high \\
\hline
\end{tabular}


Table 3. Criteria for student active participation in population.

\begin{tabular}{cc}
\hline Percentage of High and Very High participation (\%) & Criteria \\
\hline $0.00-20.99$ & Very low \\
$21.00-40.99$ & Low \\
$41.00-60.99$ & Moderate \\
$61.00-80.99$ & High \\
$81.00-100.00$ & Very high \\
\hline
\end{tabular}

\subsubsection{Determining the teacher's performance}

The method for determining the teacher's performance scale uses the same procedure as the determination of the student's active participation scale (Equation 1). The calculation of interval scale in determining the teacher's performance is presented as follows:

Interval Scale $=\frac{(5 \times 30)-(1 \times 30)}{5}=24$

There are 30 questions asked, with a choice of answers tailored to the focus question, answer A (score 1), B (score 2), C (score 3), D (score 4) and E (score 5). The questionnaires were related to the understanding of the school's vision and mission, the planning of the teaching program, the teaching method, the use of the school facilities and its involvement in programs that support the Environmental Sustainability, modified from the guidance of Adiwiyata (KemenLH dan Kemendikbud 2007). The individual criteria of teacher's performance were based on Table 4. The teacher's overall performance of the population was conducted using criteria as listed in Table 5. The effect of performance of teacher on the implementation of the environmental sustainability on the active participation of the students was analysed descriptively analytically.

Table 4. Teacher's performance criteria.

\begin{tabular}{cc}
\hline Total score & Criteria \\
\hline $30-54$ & Very low \\
$55-78$ & Low \\
$80-102$ & Moderate \\
$103-126$ & High \\
$127-150$ & Very high \\
\hline
\end{tabular}

Table 5. Teacher's performance criteria in population.

\begin{tabular}{cc}
\hline Percentage of High and Very High performance (\%) & Criteria \\
\hline $0.00-20.99$ & Very low \\
$21.00-40.99$ & Low \\
$41.00-60.99$ & Moderate \\
$61.00-80.99$ & High \\
$81.00-100.00$ & Very high \\
\hline
\end{tabular}




\section{RESULT AND DISCUSSION}

\subsection{Student's active participation in environmental sustainability}

The results of the questionnaire on active participation of student are presented in Table 6.

Table 6. Questionnaire results concerning student's active participation in maintaining environment sustainability.

\begin{tabular}{clcc}
\hline Total score & Criteria & Total student & Percentage of the population (\%) \\
\hline $20-36$ & Very low & 6 & 1.37 \\
$37-52$ & Low & 207 & 47.37 \\
$53-68$ & Moderate & 210 & 48.05 \\
$69-84$ & High & 14 & 3.20 \\
$85-100$ & Very high & 0 & 0 \\
\hline & Total & 437 & 100 \\
\hline
\end{tabular}

The results of questionnaires related to the active participation of the students of Gonzaga High School, Jakarta and Loyola High School, Semarang in terms of maintaining environment sustainability indicate that the students whose participation is high and very high is only $3.2 \%$ from 437 students. Students are more likely to participate in doing something positive for environmental sustainability with frequent or frequent frequencies such as putting the trash in place, cleaning the house, avoiding the use of plastics and styrofoam, turning off electricity and taps when not in use and using paper on both sides. Meanwhile, for the participation in activities that are not directly faced by students in their daily life such as their involvement in processing waste, taking care and planting trees, consecrated work, become motivators, campaigns and involvement in scientific forums, participation is very low (Figure 1). Based on the effectiveness criteria of the environment sustainability related to active participation of students in Table 3, the level of active participation of students in both schools is very low.

Active participation of students is the manifestation of student behaviour. Related to this, knowledge does affect a person to form his belief in terms of taking a certain attitude. Attitude is a capital owned by students to be able to act in accordance with their knowledge. Attitudes to environmental issues that are high can be interpreted that the level of care is high, but attitude is only one thing that affects the formation of intentions and intimately that will affect whether someone will behave certain or not. While the intentions are also influenced by the prevailing subjective norms, the students' attitudes are good, but not at the will/intensity, this is in line with the Theory of Reasoned Action from Ajzen and Fishbein (Vallerand 1992). 


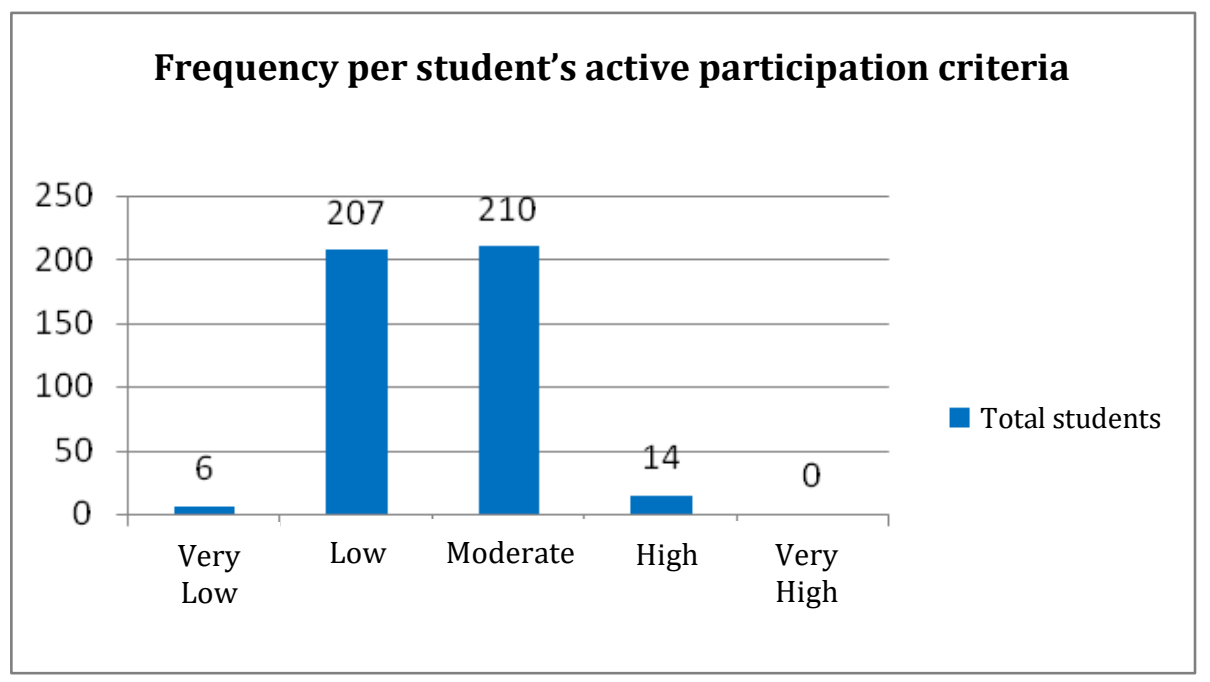

Figure 1. Level of student's active participation in maintaining the environment sustainability.

\subsection{Teacher's performance in the implementation of environment sustainability}

Questionnaires on performance of teacher were given to 47 teachers of Gonzaga High School, Jakarta and 48 teachers of Loyola High School, Semarang. The results indicated the percentage of teachers included in the criteria of high and very high performance in the implementation of environment sustainability which only amounted to $12.63 \%$. Based on the criteria of teacher's performance in the implementation of the existing environment sustainability in Table 5, the data indicates that performance of teacher is very low. The results of the questionnaire on performance of teacher are presented in Table $\mathbf{7}$ and Figure 2.

Table 7. Questionnaire results concerning on teacher's performance.

\begin{tabular}{clcc}
\hline Total score & Criteria & Total student & Percentage of the population (\%) \\
\hline $30-54$ & Very low & 1 & 1.05 \\
$55-78$ & Low & 32 & 33.68 \\
$80-102$ & Moderate & 50 & 52.63 \\
$103-126$ & High & 12 & 12.63 \\
$127-150$ & Very high & 0 & 0.00 \\
\hline & Total & 95 & 100 \\
\hline
\end{tabular}

Teacher's performance indicators in this study are interrelated, but when reviewed one by one, the evaluation of teacher's performance in the implementation of environment sustainability in Gonzaga High School, Jakarta and Loyola High, Semarang can be described as will be explained in the following sub-chapters. 


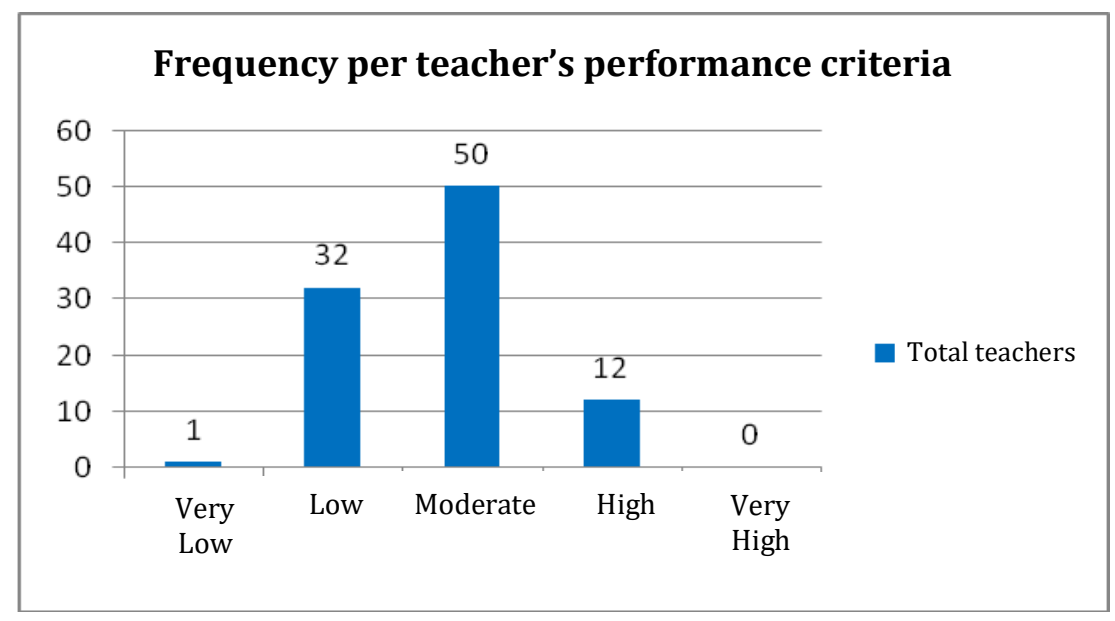

Figure 2. Level of teachers' performance in the implementation of environment sustainability.

\subsubsection{Understanding of school vision and mission}

Most teachers have understood and tried to help realize the vision and mission of the school including those related to environmental concerns. Based on the questionnaire results, the socialization on the integration of EE from the school leadership is experienced by most teachers only once a year. Teacher's comprehension about the vision and mission of the school will coloring the process of teaching and mentoring from teachers to learners. The teachers at Gonzaga and Loyola High School are required to understand the meaning of 3C (Competence, Conscience and Compassion) and the motto of Ad Maiorem Dei Gloriam (For the greater of God's glory) which is furthermore contemplated into the teaching program. However, based on interviews of teachers and vice principals in the curriculum of Loyola and Gonzaga High Schools, the teachers' understanding of school vision and mission and school value is rarely evaluated by the school's principal (within one year only a one-time question).

\subsubsection{Planning of teaching program}

The preparation of teacher program plans related to the environment sustainability requires an understanding of ongoing environmental issues, while based on data obtained from the questionnaires, the number of teachers with high intensity in terms of studying environmental issues is only $48 \%$, teachers who are aware of the integration policy of environment sustainability in the curriculum only $32 \%$. The number of teachers who linked their lessons to environmental issues was only $28 \%$, the number of teachers who included environment sustainability in their lesson plan at least $20 \%$ of teaching materials was only $27 \%$, the number of teachers who held discussions with his team teaching related to the delivery of environment sustainability materials with considerable intensity was only $3 \%$ and teachers actively participating in 
discussion forums with other school teachers was only $7 \%$. These points indicated that in the planning of teachers' teaching program performance is still very low. Such situations are likely to occur because the socialization of the integration of environment sustainability in the curriculum by school leaders is rare, teacher supervision by school's principal does not emphasize the delivery of environment sustainability materials in all lessons and a lack of teacherrelated competency development.

Preparation of a less down-to-earth curriculum, less linking material related to things familiar to everyday life can hamper achievement of results. Likewise, in environmental education, the delivery of material of environment sustainability only delivered in some subjects less influence on improving students' motivation to participate in maintaining environmental sustainability. This is in line with Payne's assertion (2006) that teachers, researchers and schools should actively build and give meaning to human interactions and relationships with the environment by bringing students to things close to their lives. Measuring the level of knowledge of students as a requirement of graduation with a larger portion of the National Examination, making the function of schools as educational institutions tend to be reduced that only provide teaching. Teachers are more likely to accompany students to achieve a standard of knowledge, rather than acquiring life skills and understanding of universal values that lead to environmental awareness.

\subsubsection{Teaching methods}

The teaching method is very important to condition the students to understand the delivery of the material taught by the teacher. The use of teaching methods by inviting students to interact directly with the environment around at least 4 times a year is only done by $32 \%$ of teachers. Group assignments allow students to discuss or exchange ideas. Group assignment by linking environmental issues at least 4 times a year, only done by $10 \%$ of teachers. Teaching methods that are more often in the classroom provide less opportunity for students to interact directly with the environment, thus less supportive of the environmental education process that fosters awareness. Teachers should pass innovations to try other ways of conveying lesson material in addition to using lecture methods, as Rideout (2005) does with the use of modules.

\subsubsection{Use of school facilities}

School principal in both studied schools have conducted socialization on optimizing the use of facilities and supporting facilities owned by the school even though there is no written policy. The existing school facilities in Gonzaga High School and Loyola High School can be used to support learning such as libraries, laboratories, gardens, lawns and parks. School facilities can serve as learning 
resources. The use of school facilities in the form of parks, gardens and grasslands can support the learning process, while from existing data indicates that the use of these facilities by teachers is still very rare and depends on the creativity of the teacher.

\subsubsection{Involvement of teachers in programs that support environment sustainability}

The development of teacher competencies of Gonzaga High School and Loyola High School related to environment sustainability either through seminars or training is still very low. Teacher support in creating clean, neat and healthy environment motivates students to save energy, save paper and save electricity usage. The involvement of teachers in setting an example to put waste in place is also high. This is a factor that supports the implementation of environment sustainability, because with the involvement of teachers in these activities can motivate students to do the same. The co-curricular activities that are conducted programmatically every year involves the teachers, so that teachers are required to be able to assist students in jamboree activities, live in, study tour and also field research. Assignment of teachers to assist students in activities outside school is always accompanied by additional incentives to teachers. This makes the teacher more responsible in performing their duties. Meanwhile, teacher assistance related to the implementation of environment sustainability in the two schools studied was not incentive, so it can be said as mentoring which is not obliged by the teachers, because there is no assignment. The administrative tasks of teaching and assessment sufficient time-consuming teachers, suspected as the cause of the lack of opportunities for teachers to provide more assistance to students, related to the environment sustainability.

\subsection{The influence of performance of teacher in the implementation of environment sustainability on the active participation of students in maintaining the environment sustainability}

The influence of each teacher's performance indicator on the active participation of students in this study is not analysed quantitatively so it is not known which indicator influence is the most dominant. The problem of one's behaviour toward the environment is the moral problem, which has been the formation since childhood. Education provided by parents is certainly very important in this process and it is certainly influenced by the level of education of their parents. The low participation of Gonzaga High School and Loyola High School students is believed to be one of them because the learning method of the teacher is mostly in the classroom so that the students' interaction with the environment becomes less, besides the environmental factors of the family and 
the environment of the urban community who tend to care less about the environment.

The interaction relationship takes place between school leader and teacher, between teacher and student, between school leader and student and between school leader and teacher with student's parents. This interaction relationship is very important for the smoothness of the educational process. Good interaction between school leaders and teachers will facilitate the program socialization process planned by school leaders. Interaction between teacher and student enables achievement of learning objectives. The interaction between school leaders and teachers in the making of a program can also enable students to interact with the environment and community, such as in camping, live in and field studies. The interaction with the social system and the natural environment can actually be managed through these activities, in line with Terry's statement (1983), that two systems to be considered in the environment are social systems and ecosystems. Learning method in Gonzaga High School and Loyola High School which is very less giving opportunity to student interaction with environment, not optimal use of environment around school as source of learning allegedly become one of cause of lack of student participation in the case of preserving environment. The interaction between students and the school environment that is not designed to provide awareness to students about the importance of the environment causes students to have less responsibility for their environment. A harmonious and balanced interaction between human, institutional, technological and natural resources must always be pursued in education, in line with Soerjani (2002).

There is a dependency relationship between students and teachers in the implementation of learning. The dependency relationship also occurs between the parents of the students and the school. Teachers as a learning designer determine the activities that students will do in learning. If the intensive draft of learning invites students to think critically related to environmental issues, then the student will get used to thinking critically related to it. The method of teaching and the use of school facilities certainly depend on the plan of the learning program prepared by the teacher. Teacher's performance data indicates that teacher's performance in terms of using discussion method, assignment, article study and mind mapping related to environmental issues is very low. Teacher's performance in the use of school facilities in the form of parks, gardens, lawns and trees is also very low.

Environment sustainability both in Gonzaga High School and Loyola High School is more delivered through the lesson of Geography and Biology lesson, whereas the material of environment sustainability can be delivered through various subjects. Many teachers find it difficult to include environment 
sustainability in the lessons they receive, as presented by Drs. Edi Asmanto, mathematics teacher of Loyola, High School and Drs. Andreas Eka Sujatmanto, the physics teacher of Loyola High School and Odilia Galuh, the chemistry teacher of Gonzaga High School. Education Unit Level Curriculum (KTSP) used by both schools actually provides a space for teachers to plan instructional programs whose achievement indicators are tailored to the students' abilities, the facilities at school and the value of the schools to be invested. The use of the backward design syllabus as a complement is an opportunity that can be used to incorporate environment sustainability into the teaching plan in all subjects. The role of the principal as a coordinator is very important to invite all teachers to understand and make the planning of teaching which is expected to further hone the students' care and responsibility to the environment. Teacher training related to the implementation of environment sustainability must be done so that all teachers have the competence to give the environment sustainability through their respective lessons.

\section{CONCLUSIONS AND SUGGESTIONS}

The active participation of the students of Gonzaga High School, Jakarta and the students of Loyola High School, Semarang in maintaining the environment sustainability can be categorized as very low and the effectiveness of environment sustainability in terms of this is classified as ineffective.

The performance of teachers in both of schools in terms of running its role in the development of environment-based learning methods, as well as the development of curricular activities to increase knowledge and awareness of students about the environment in terms of understanding of school vision and mission, program planning, the use of school facilities and involvement in programs that support the environment sustainability is very low, with the percentage of teachers included in the criteria of high performance and very high by $12.63 \%$ of the total population of 95 teachers. Performance of teacher related to the preparation of environment sustainability related teaching program plan is very low, so the teaching method does not give students the opportunity to interact with their environment. This is thought to be a factor causing the low participation of students in maintaining the environment.

\section{REFERENCES}

Barab SA and Roth W. 2006. Curriculum-based ecosystems: supporting knowing from an ecological perspective. Educational Researcher 35(5):3-13. https://doi.org/10.3102/0013189X035005003.

Chusmeru P. 2001. Komunikasi di tengah agenda reformasi sosial politik. Alumni. Bandung. 
Finch K. 2008. Extinction of experience: a challenge for environment education. New England Journal of Environmental Education 1-5.

[KemenLH dan Kemendikbud] Kementerian Lingkungan Hidup dan Kementerian Pendidikan dan Kebudayaan. 2007. Panduan adiwiyata wujudkan sekolah peduli dan berbudaya lingkungan. KemenLH dan Kemendikbud. Jakarta.

Keraf AS. 2010. Etika lingkungan hidup. PT Kompas Media Nusantara. Jakarta. Koesoema AD. 2009. Pendidik karakter di zaman keblinger. Grasindo. Jakarta.

Mikkelsen B. 2001. Metode penelitian partisipatoris dan upaya-upaya pemberdayaan. Yayasan Obor Indonesia. Jakarta

Law Number 32 of 2009 on Environmental Management and Protection.

Payne PG. 2006. Environmental education and curriculum theory. The Journal of Environmental Education 37(2):25-35. https://doi.org/10.3200/JOEE.37. 2.25-35.

PPSML. 1993. Efektivitas pendidikan lingkungan (studi di SMA 8 dan SMA 38). UI Library. Jakarta.

Rideout BE. 2005. The effect of a brief environmental problems module on endorsement of the new ecological paradigm in college students. The Journal of Environmental Education 37(1):3-11. https://doi.org/10.3200 /JOEE.37.1.3-12.

Soemantojo RW. 2004. Pendidikan dan etika lingkungan hidup. Jurnal Lingkungan dan Pembangunan 24 (1):17-29.

Soerjani M. 2002. Ekologi manusia edisi 2. Penerbit Universitas Terbuka. Tangerang.

Sugandhy A and Hakim R. 2007. Prinsip dasar kebijakan pembangunan berkelanjutan berwawasan lingkungan. Bumi Aksara. Jakarta.

Terry RA. 1983. Conceptual approach to human ecology. East-West Center. Hawaii.

[UNESCO] United Nations Educational, Scientific and Cultural Organization. 1975. The Belgrade Charter: a framework for environment education. Belgrade.

Vallerand RJ, Deshaies P, Cuerrier JP, Pelletier LG and Mongeau C. 1992. Ajzen and Fishbein's theory of reasoned action as applied to moral behaviour: a confirmatory analysis. Journal of Personality and Social Psychology 62(1):98-109. https://doi.org/10.1037/0022-3514.62.1.98.

Widiasih. 1999. Kajian terhadap pengajaran konsep ilmu pengetahuan alam (IPA). Jurnal Pendidikan 31(1999):65-72.

Wiggins $G$ and McTighe J. 2005. Understanding by design. ASCD. Virginia. 